\title{
SOCIAL NOTION IN THE ARTISTIC EXECUTION OF MANAS KUMAR SAHOO'S
} SAND ANIMATION

\section{RANJAN KUMAR MALLIK}

Chitkara School of Art and Design, Chitkara University Punjab, India

\section{ABSTRACT}

Manas Kumar Sahoo is a well-known sand sculptor and animator of India, was born in a traditional family of Odisha. From childhood, he was very much fascinated with education and wants to acquire a unique position. His artistic skills through sand art and sand animation have provided his artistic position on the real ground and he becomes a young star in the Odishan art scenario. This study explores his artistic journey to open-up his artistic vision and responses to society. This paper focuses on his sand animation and explored his unique way of presentation/ performance. It also deals his methodological process to know his methods of execution a body of artworks. Via adopting qualitative methodology, this paper highlights his artistic journey and sensibility for the sake of society.

KEYWORDS: Sand Animation, Artistic Environment of Odisha, The art of Manas Kumar Sahoo, Art \& Social Responsibility

Received: Jun 06, 2020; Accepted: Jun 26, 2020; Published: Aug 21, 2020; Paper Id.: IJMPERDJUN2020837

\section{INTRODUCTION}

Oriya personality had its glorious expression when the Oriyas as Kalingans faced the Magadhan invader Asoka's imperial threat and through their bravery, bravery, loyalty, and sense of duty brought a sea change to Chandasoka's mind and transformed him into Dharmasoka ${ }^{[1]}$. The Kalingans' colonial aspiration was materialized with the Chedi king Mahameghavahana Aira Kharavela who was able to prove his mettle as a great ruler, a great national nationalist and a great patronage ${ }^{[4]}$. Historically, it has a great tradition of classical and folk tradition of visual art forms. Temple architecture, stone sculptures and Patt-Paintings etc are some of the evidences which show its magnificent cultural legacy in contemporary times. Manas Kumar Sahoo is the part of this legacy. He was Born in the land of Lord Jagannath, Puri, Odisha to a middle-class family. The land of Puri is very fartile for artistic creation. It provides a very strong background for artistic production in many visual forms. Unknowingly he has been playing with Puri See beach sand since his kid age. He then communicates his thoughts through air on Lord Jagannath's grace and blessing, he passes by with sand. With the blessing of Lord Jagarnath and encouragements of local people/artists, he has been able to work with sand art. He has started art works with sand artist's friends of Puri, Odisha. But his family is part of art tredition and his parents Prahalad Sahoo and Manorama Sahoo have been doing sand painting from a long time. Through them he has taken so many inspiration of art execution naturally. Gradually, he has developed his artistic skill in sand sculpture and sand animation. He has taken part in many exhibits of sand art held in India \& Overseas. He becomes one of the influential artists of Puri, Odisha very soon. His hard work and dedication have won him both national and international renown in this short period of time. 


\section{UNIQUENESS OF SAND ANIMATION: MANAS KUMAR SAHOO}

The sand animation of Manas Kumar Sahoo is very much inspired by the art of Odisha which is narrative in nature. He has taken it as a base for his artistic production. In his sand animation production, he has provoked a story telling skill to propagate his ideas. He is also very much inspired with artist Kseniya Simonova and her incredible Sand Art on Ukraine's Got Talent. He has derived a lot of changes after realized this added a team of technical persons and supporters to play sand animation in powerful manner. Basically, Sand animation has always been a solo production before Manas Kumar Sahoo used the collective collaboration in this piece of art for the first time effectively. The team members are Manas Kumar Sahoo, Suchitra Mahasweta, Bulu Mohanty, and Monalisa Sahoo are in the squad ${ }^{[2]}$. They did the subject of global warming by animating the air. This sand artist's squad is the world's biggest sand animation unit. In the famous Indian reality show 'India's Got Talent "Khoj 2" in COLORS, a channel which is a sister concern of the renowned network company "NETWORK -18"[3]. He collaborated with his team and their results left the judges and audience speechless. He always focuses with two things Clarity and Quality. Along with Voice over, Music, Camera Angel, script, Frame work of Sceen and Shots etc. According to Manas Sahoo most Important challenge are Concept, Time and execution in a particular space frame. He claimed he was the first sand art animator in India (figure 1,2). Who first time got award in India Got Talent in India Telivision and Special Showcase in Satyamev Jayete by Indian Bollywood Cine Star Amit Khan and many National and International Platform. Individual creation of one concept to motion through unusual locally available sand medium is the best DNA of Manas Kumar Sahoo sand animation.
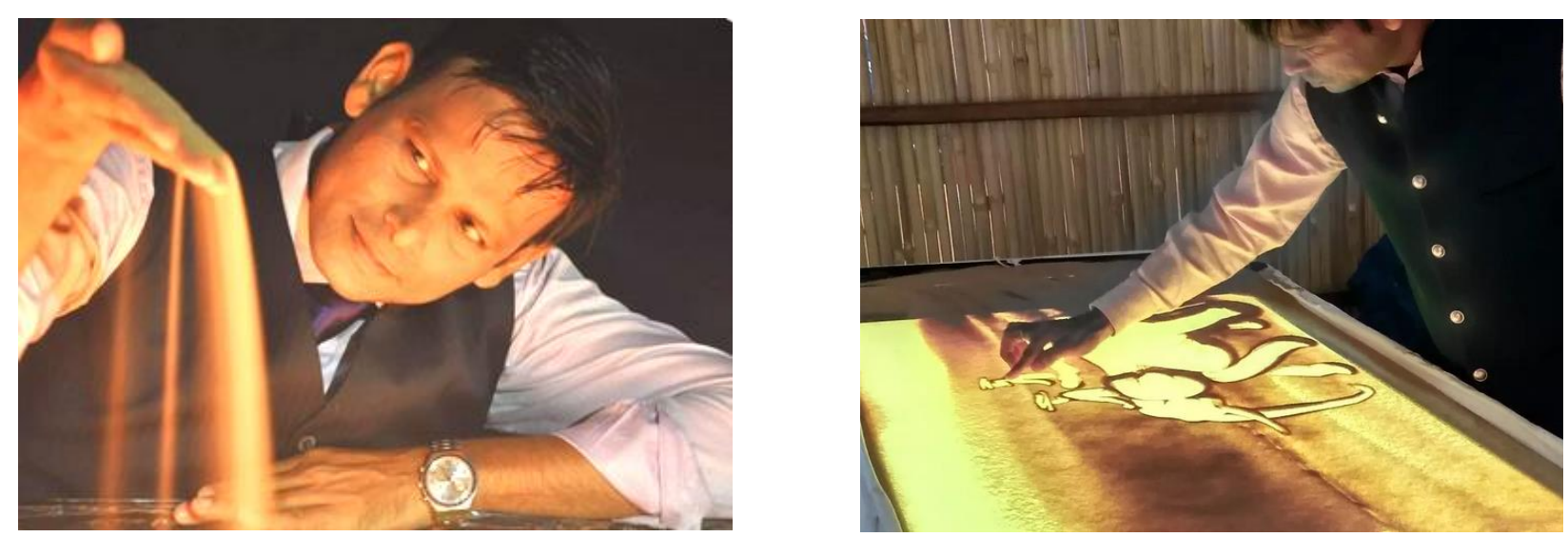

Figure 1\& 2: Manas Kumar Sahoo (Sand animation). Retrieved 29th April 2020 from http://www.manassand.com/sand-animation/page-15111177.

\section{LOCAL AND GLOBAL REORGANIZATIONS}

Recognition, encouragement, inspiration, references and cultural backup, these all the aspects is very-very significant for an artist growth. It provides an atmosphere to work with full enthusiasm and motion. It creates an environment for holistic growth. Manas Kumar Sahoo is the evidence of these harmonies. From the beginning of his career, he has proved his potential because of the cultural backup and appreciation of Puri, Odisha. Gradually he becomes the important part of Odisha state and recognised as 'PRIDE OF ODISHA-2010', by "TARANGA. He has won the top 20 Most Inspirational Personalities of Odisha Awards in 2019. So it is visible and felt by the researcher that within the decade, he become successful to establish him as an important creator in local as well as a global platform. He has recognised by the famous Indian reality show 'India's Got Talent Khoj 2 in COLORS and played an important role in established his idea. In 2019, he has awarded from the international conference on biodiversity and sustainable development strategies for future and 
Shree-Kshetra Ratna award. He was facilitated by Puri, Odisha many-many times in local or international events. In 2018, he has won the special appreciation award at 'Konark international Cyclothon' and best compliments by 'Finxera'. In this year, He has also felicitated by Nitish Kumar, Honourable CM of Bihar (state-India), on the occasion of 'International Drug-free Day' Govt. of Bihar 2018.

He is one of the cultural warriors of Odisha (India) and has established himself as an adequate performer in sand sculpture and sand animation. On the basis of this, he has won 'Shree Jagannath Chetna Pratibha Samman' in 2015. In this year he has also recognised as achievers of Odisha from The Times group, the award given by the Minister of State (I/C) for Petroleum and Natural Gas Dharmendra Pradhan. In 2014, on the occasion of 'World Environment Day', got an award which has been given by State Pollution Control Board and The Times of India, presented by The Hon'ble Governor of Odisha Dr S.C. Jamir. In this year he has also received 'MDTV' Entertainment Award “ACHIEVER. In 2013, he has been facilitated by 'Rashtriya Ratna Award' by FFI, India and also awarded 'Bharat Excellence Award' at New Delhi. In 2011 he has won 'Shreekhetrashree Award' and the 'Best Achievers Award' by Indian Railway (East Coast Rly Division) in 2010. In 2010 he has been felicitated "ZINDAGI LIVE" award by Richa Anirudh from CNN-IBN networks for Sand Animation Art. In this year He has been appreciation award by Sir Vittorio Colao(Global Chief), VODAFONE ESSAR Cellular Limited at Pune. So, It is visible that Manas's continuous efforts have been enabled him to make his creative world full of vigour and it is recognised by the world.

\section{THE SOCIAL NOTION IN THE ART OF MANAS KUMAR SAHOO}

Mother Nature, globalization, and human society surround every artist and human being. The contemporary economic structure is related to every human being and has affected the region. The existing world is growing per se and manipulating physical and virtual space in order to propagate their economic plan worldwide. Now, the whole human being is market-dependent and has put himself as a key role for the economic growth of every society and country. Thus, global economy affects each and controls the cycle of thinking over the life of the person. Just as Mother Nature is one of the basic things, it surrounds and rules human beings with this. Nature is also a source of learning for human beings from the begging of human civilization. Spontaneous act of Nature is born in the mind and soul of man.

Manas Kumar Sahoo is also governed with the contemporary situations and has enabled it to propagate his ideas accordingly. These activities are inherited in his body, mind and soul. In this way if someone sees/evaluate the artworks of Sahoo, these all phenomenon is visible in his artistic output. Sahoo's works have a significant effect on social and political circumstances. He speaks a lot about this ecological catastrophe, established events, regional stability and religious tolerance. Manas Kumar Sahoo's artistic work is often compared with the common art form. It is always visible that his methodology of practicing art is developed in a multi directional where artistic skill is developed in a popular way. His sense of structure is structurally rather formal, and straightforward in language. It is referenced as poster art where the idea or the subject matter is manipulated / designed for direct communication or propagation. His method of creating an image is synonymous with Odisha's temple sculpture. This field is very closely linked to traditional styles of painting. Such types of art are very creative in their composition and guide towards the narration of his ideas. His sand animation demonstrates lyrical figurative heritage and simplistic ability in carving. He has clearly referenced the decorative motif that is used in Odisha's traditional art. He also seeks to expand his concept for the sake of current social problems with the aid of certain cultural strengths. 'Covid 19' is not only a scientific problem of this term but turns the modern society into a socioeconomic catastrophe (fig. $34,5,6$ ). With this sand animation with the quote 'I stayed at work for you, you stay at home for 
me,' he aims to show the doctors' and whole medical team's commitment to battling the Corona tragedy.
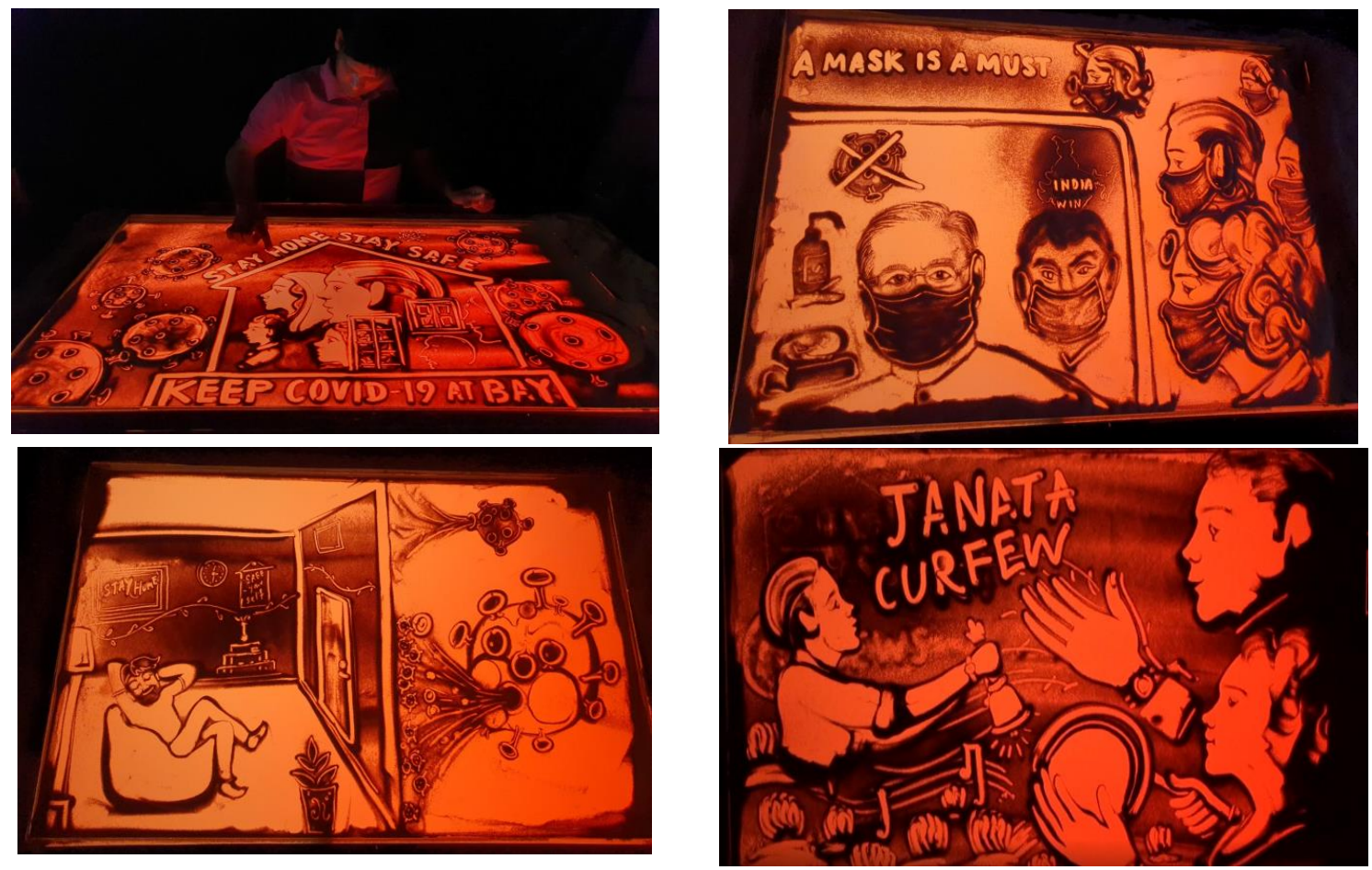

Figure 3, 4, 5 \& 6: Manas Kumar Sahoo (2019). Retrieved 29th April 2020 from http://www.manassand.com/sand-animation/page-15111177

There is a theme of recognition of socio-political problems in the work of Manas Kumar Sahoo. The topic of terrorism is often propagated by the state in relation to anti-national activity. And it becomes the general conception of life for people in the long run. But opposing this notion is important when a State propagates a culture as anti-national. Sahoo's method of thought against is driven by general phenomenon. To some extent the State governs or manipulates his ideology. And as he develops images in regards to extremism, he is very close to the philosophy of the state (fig.3). Yet one thing that is unique in this sense is that he is really open-up a discourse to discuss this socio-poitical agenda before the nations and cultures. For instance his artwork related to Anna Hazare (figure7) open-up a debate against established state norms vs. required establishment. In 2014 Anna Hahare become one of the important figures for Indian mass and become very popular for Ahimsa movement.

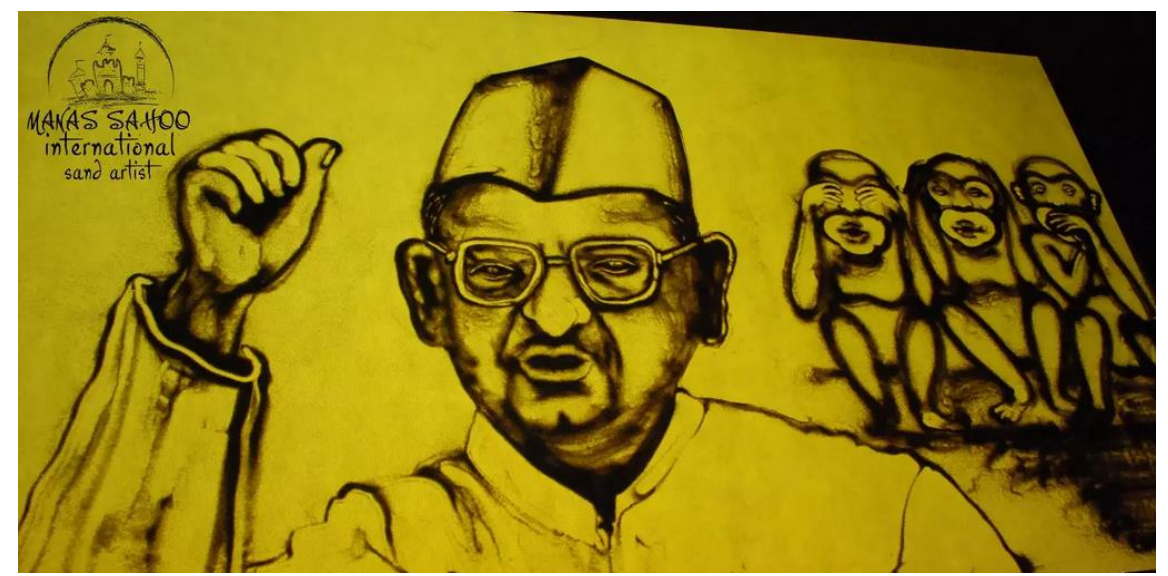

Figure 7: Manas Kumar Sahoo (2013). Retrieved 29th April 2020 from http://www.manassand.com/sand-animation/page-15111177. 


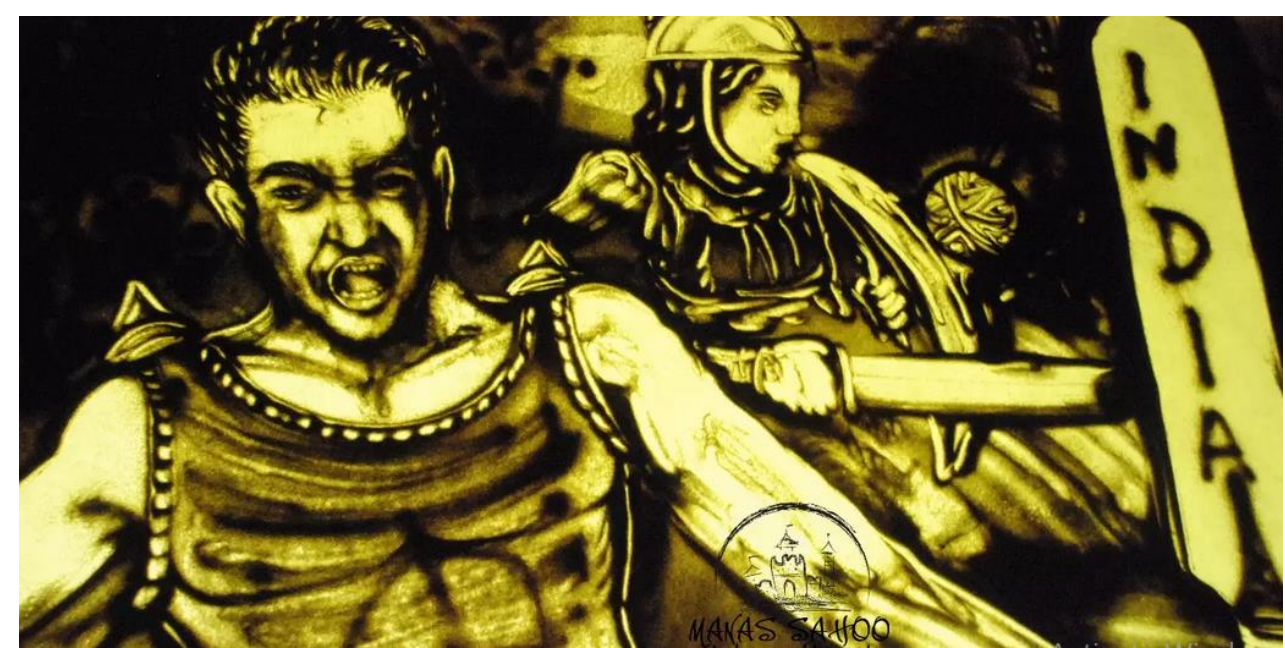

Figure 8: Manas Kumar Sahoo (2016). Retrieved 29th April 2020 from http://www.manassand.com/sand-animation/page-15111177.

Manas Kumar Sahoo has created a kind of skill which has strengths of resistance. Through it, he has commented on several social incident and occasions. With his sand animation he has propagated his performance reference to Nirbhaya rape case. It was one of important case in Indian history, because people become unite to file against this kind of incidents Manas have manipulated this notion in his 'Nirbhaya' related sand animation performance (fig. 9). It was executed by his team and it was explored with light, sound and actions. The performance was very powerful in expression and has established his potential Indian art field. It is visible that he manipulates popular themes for his artistic creations and carved it for his art performance. From this, he become able connects with local people and establish himself as a important innovator. It is the way of popularization of ideas which is locally and internationally existed everywhere. The animation performances on 'Ambedkar Jayanti' or 'Hanuman Jayanti' are the part of this strategy (fig. 10, 11). In his artistic performance, he also tries to express the current situation. His sand art performance on 'Namaste Trump' is the best evidence of this notion (12). From this he always tries to connect himself with government initiatives, institutional initiatives or local initiatives. His sand art animation is new for Indian art and has one of the leading figures in it. Within a decade he has experiment this art form for his expression and popularizes it in the mass. He has developed a narrative format to express his ideas with full vigor. It is one of his important contributions in Indian art and culture.

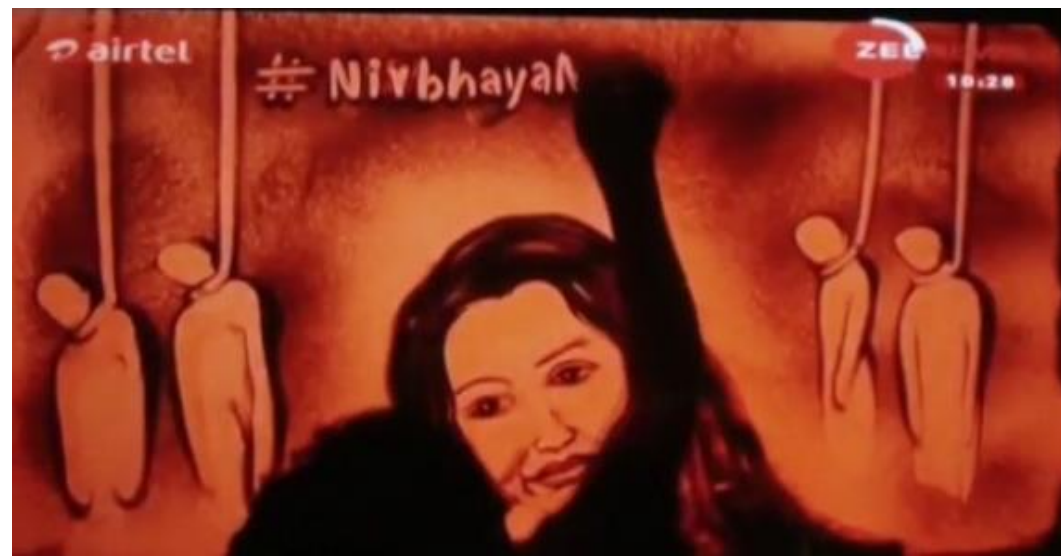

Figure 9: Manas Kumar Sahoo (2017). Retrieved 29th April 2020 from http://www.manassand.com/sand-animation/page-15111177. 


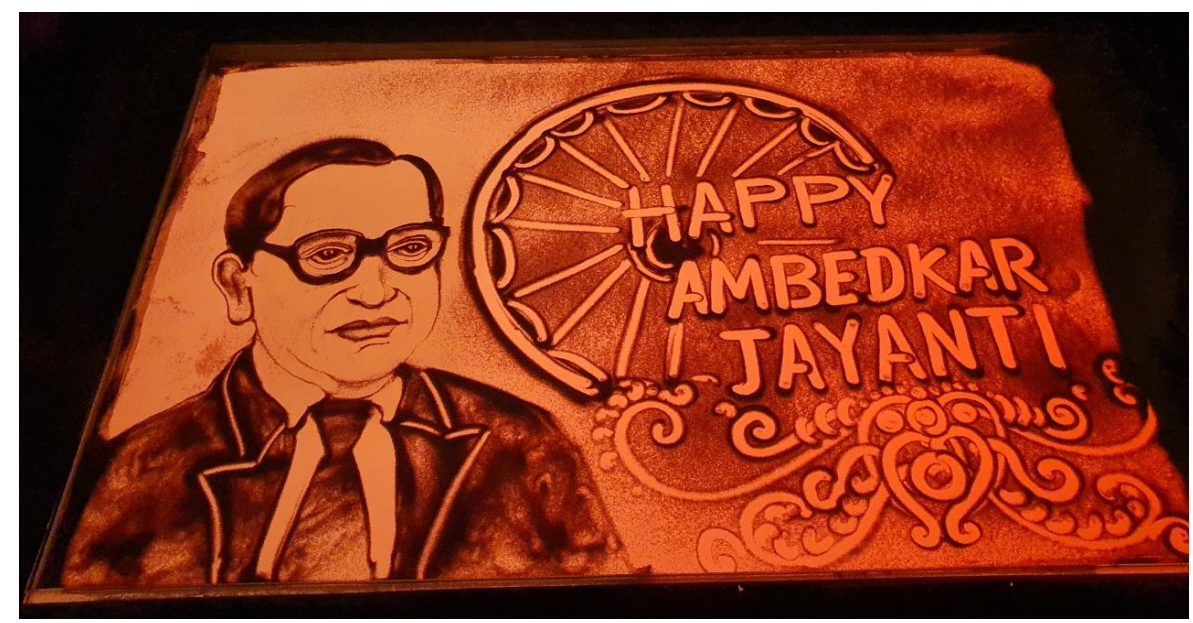

Figure 10: Manas Kumar Sahoo (2020). Retrieved 29th April 2020 from http://www.manassand.com/sand-animation/page-15111177

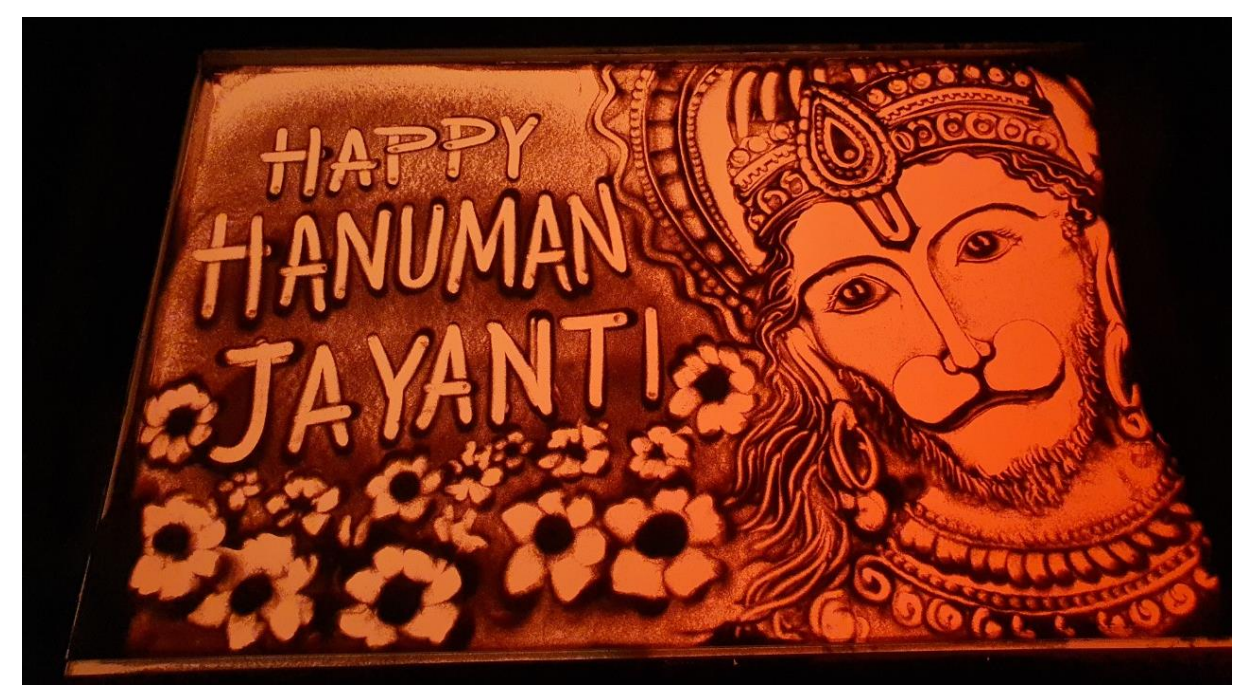

Figure 11: Manas Kumar Sahoo (2019). Retrieved 29th April 2020 from http://www.manassand.com/sand-animation/page-15111177.

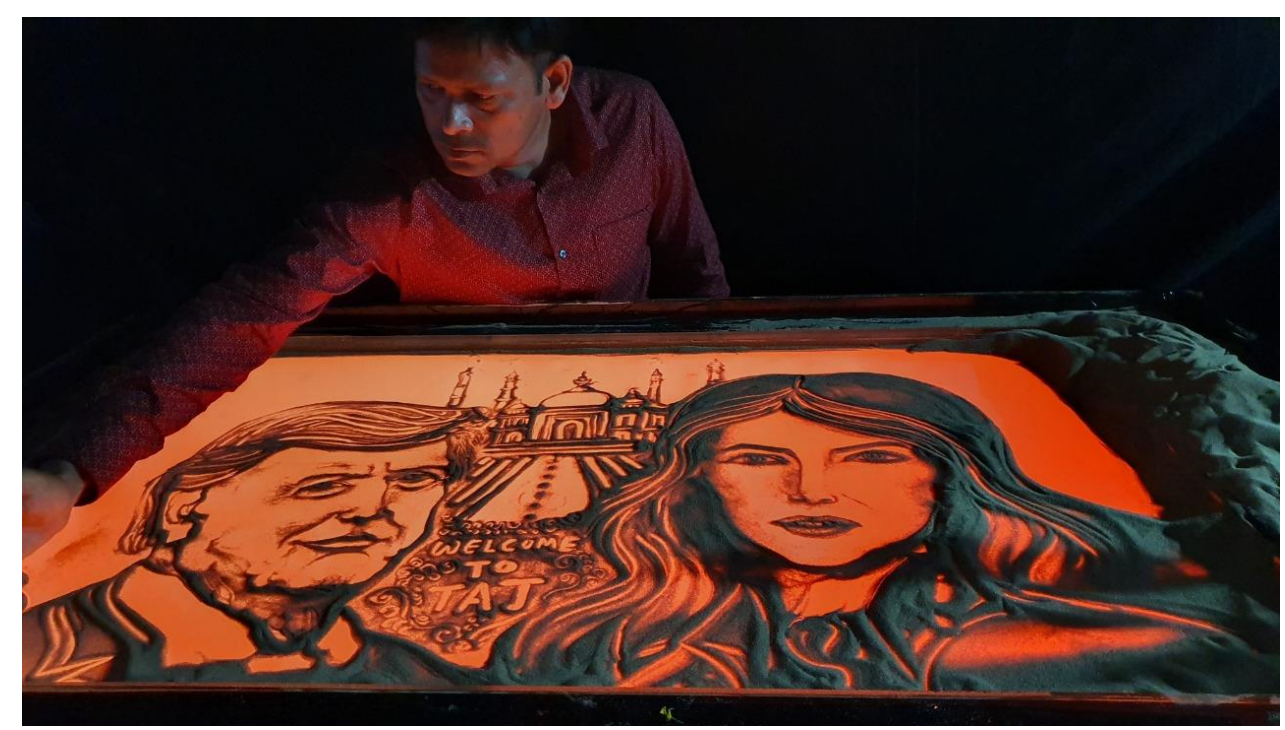

Figure 12: Manas Kumar Sahoo (2020). Retrieved 29th April 2020 from http://www.manassand.com/sand-animation/page-15111177 


\section{CONCLUSIONS}

Mans Kumar Sahoo's sand animation art is an expressive medium of expression that forms the notion of popular presentation / performance. It is planned and performed at the place or cultural occasions of the people. Because of this, people are easily linked to these presentations of art. And many of his art presentations discuss existing social problems. His art practices can be traced in a way; where he consolidates his substance, shape, methods and materials in complete harmony. For this reason, his systematic sand animation presentation is carried out in a perfect manner of propagating his ideas. It is accumulated over the course of time, as per his thought process. Globally, his famous works on sand animation has received multiple national and international awards. His art forms are on today's social issues. These art forms basically have intense forms of social degradation, social diseases, today's society, etc. Even if he knows that the nature of his art form is temporary, but that he always manages to attract people's attention to convey his ideas vigorously. He is definitely an inspiration for young artists.

\section{REFERENCES}

1. Mohapatra, H. K. (2008). Cultural resurgence in Orissa during the post independence era. Orissa Review, $2008,1-10$.

2. Manas Kumar Sahoo (2017). Retrieved 29th April 2020 from https://starclinch.com/manas-kumar-sahoo-group

3. Nuaodisha (2016). Retrieved 29th April 2020 fromhttps://www.nuaodisha.com/Eminet_Personalities/Manas-KumarSahoo.aspx

4. Das, M. K. Cultural Heritage Management. "Evolution", 1, 49.

5. Manas Kumar Sahoo (Sand animation). Figure-1,2. Retrieved 29th April 2020 from http://www.manassand.com/sandanimation/page-15111177

6. Manas Kumar Sahoo (2019). Figure-3,4,5,6. Retrieved 29th April 2020 from http://www.manassand.com/sandanimation/page-15111177

7. Manas Kumar Sahoo (2013). Figure-7. Retrieved 29th April 2020 from http://www.manassand.com/sand-animation/page15111177

8. Manas Kumar Sahoo (2017). Figure-9. Retrieved 29th April 2020 from http://www.manassand.com/sand-animation/page15111177

9. Manas Kumar Sahoo (2020). Figure-10. Retrieved 29th April 2020 from http://www.manassand.com/sand-animation/page15111177

10. Manas Kumar Sahoo (2019). Figure-11. Retrieved 29th April 2020 from http://www.manassand.com/sand-animation/page15111177

11. Manas Kumar Sahoo (2020). Figure-12. Retrieved 29th April 2020 from http://www.manassand.com/sand-animation/page$\underline{15111177}$

12. Issundari, Sri, and Iva Rachmawati. "The Role of Citizen in Indonesian Public Diplomacy Through IACS (Indonesian Arts and Cultural Scholarship) Program." International Journal of Political Science, Law and International Relations (IJPSLIR) ISSN (P) (2016): 2278-8832.

13. Mudassir Khan, Mohd Ayyoob. "The scope of E-learning in the computer science \& technologies." International Journal of Computer Science Engineering and Information Technology Research (IJCSEITR) 6.6 (2016): 93-98. 
14. Senthilkumar, B., and H. Samuel Thavaraj. "An evaluation of TPM implementation in clothing industry in India-a lean philosophy based approach." International Journal of Industrial Engineering \& Technology (IJIET), 4 (6), 11 18 (2014).

15. Ansari, Amna, Maria Ansari, and Farjad Faiz. "Kashi Kari in Wazīr Khan Mosque." International Journal of History and Research (IJHR) 6.2 (2016): 1-12. 